Institute of $\mathbf{F}_{\text {ood and }} \mathbf{A}_{\text {gricultural }} \mathbf{S}_{\text {ciences }}$

\title{
Grandparents Raising Grandchildren: Navigating the System Part 2 - Legal Issues ${ }^{1}$
}

Millie Ferrer and Angela Falcone ${ }^{2}$

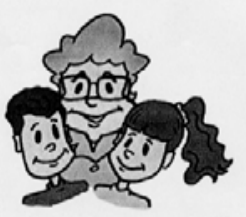

Goal: To provide grandparents with information about Florida's legal system as it relates to grandparents raising grandchildren.

Grandparents face many responsibilities in their new role. If you become a long-term care provider, you will be affected by the legal system. You can be an advocate for you grandchild's rights by knowing about the system and where to go for help.

Florida has one of the highest numbers of grandchildren living in grandparent households. In the past, there were few rights given to relative caregivers. Now, these rights are improving. For example, Florida has approved a program that pays relatives to care for dependent children called the Relative Caregiver Program. (See Navigating the System Part 1.)

Your legal rights will be determined by how much responsibility you accept for your grandchild. By knowing your legal rights, you will have more control over what happens to him*. Before you make a decision concerning your grandchild, always remember to ask yourself, "What will happen if I...?"

\section{Custody Options}

In caring for grandchildren, grandparents have several custody options. To decide which options match your needs, you must become

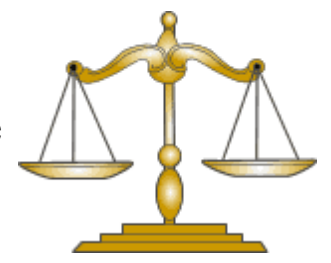

1. This document is FCS 2189-Eng, one of a series of the Department of Family, Youth, and Community Sciences, Florida Cooperative Extension Service, Institute of Food and Agricultural Sciences, University of Florida. Publication date: January 2002. Reviewed by Anne Fugate, Project Coordinator, University of Florida, for Florida's CYFAR State Strengthening Grant, Maisie Ross, Extension Agent III, and Stephanie Toelle, Extension Agent III. Thanks to Erica Murphy, UF undergraduate student, for her support and assistance. Please visit the EDIS website at http://edis.ifas.ufl.edu

2. Millie Ferrer, Ph.D., Associate Professor, Human Development, and Angela Falcone, Ed.S., Graduate Assistant, Department of Family, Youth and Community Sciences, Cooperative Extension Service, Institute of Food and Agricultural Sciences, University of Florida, Gainesville, 32611.

The Institute of Food and Agricultural Sciences is an equal opportunity/affirmative action employer authorized to provide research, educational information and other services only to individuals and institutions that function without regard to race, color, sex, age, handicap, or national origin. For information on obtaining other extension publications, contact your county Cooperative Extension Service office. Florida Cooperative Extension Service / Institute of Food and Agricultural Sciences / University of Florida / Christine Taylor Waddill, Dean 
familiar with legal terms. Courts classify families in two ways:

$\begin{array}{ll}\hat{I} & \text { families with dependent children } \\ \text { families without dependent children }\end{array}$

A family with a dependent child receives ongoing supervision by a case worker from the Department of Children and Families (DCF). A child can become dependent on the State if a child has been abused, neglected, or abandoned by a parent. Dependent children are also called adjudicated dependent. Families without dependent children do not receive on-going supervision by DCF. What category does your family belong to?

(fill in the blank)

The custody options available for families without dependent children are not the same as those with dependent children. On pages 3 and 4 you will find two charts that describe these custody options. The first chart outlines options for families with DCF involvement. The second chart outlines custody options for families without DCF involvement.

After reading the custody options on pages 3 and 4 , review the following situations and decide which custody option would be best for a grandparent.

\section{$\underline{\text { Situation }}$}

1. After taking care of her grandchild for over three years, Mrs. Johnson wants to secure the most permanent custody for her grandchild. What is her best option?
2. Mrs. Simmons' grandchildren just moved in with her due to parental drug abuse. She is uncertain that her daughter will be willing to follow her case plan to get her children back. What option does Mrs. Simmons have?

(fill in the blank)

3. Mr. and Mrs. Garcia agree to take care of their grandchildren while their parents reestablish themselves in a new location. What is the best custody option?

(fill in the blank)

4. Mrs. Smith has been caring for her grandchildren for over six months. During that time, the family has been supervised by a DCF caseworker. Mrs. Smith wants to seek a more secure and permanent arrangement because her daughter is not following her case plan. What options are open to Mrs. Smith?

(fill in the blank) see page 5 for answers






\section{Custody Options Without Department of Children and Families (DCF) Involvement}

\begin{tabular}{|c|c|c|c|c|}
\hline & Description & Grandparent's rights & Parent's rights & Best choice if ... \\
\hline $\begin{array}{l}\text { Informal/ } \\
\text { Physical Custody }\end{array}$ & $\begin{array}{l}- \text { most common } \\
\text { - not considered legal } \\
\text { custody }\end{array}$ & $\begin{array}{l}\text { - grandparent has no legal right to make } \\
\text { important decisions for child } \\
\text { - with durable power of attorney from } \\
\text { parent, grandparent's custody is } \\
\text { strengthened } \\
\text { - power of attorney can be taken away at } \\
\text { any time by the parent who granted it }\end{array}$ & $\begin{array}{l}\text { - parents can take child back } \\
\text { at any time } \\
\text { - parents still have legal } \\
\text { rights }\end{array}$ & $\begin{array}{l}\text { - parent and grandparent are } \\
\text { in agreement }\end{array}$ \\
\hline $\begin{array}{l}\text { Temporary } \\
\text { Custody }\end{array}$ & $\begin{array}{l}\text { - legal form of custody } \\
\text { - for a specific length of } \\
\text { time, possibly until } \\
\text { child is } 18\end{array}$ & $\begin{array}{l}\text { - grandparent can strengthen this custody } \\
\text { by moving the case to dependency court } \\
\text { if the parent proves to be unfit } \\
\text { - custody order determines the decisions } \\
\text { grandparent can make for grandchild }\end{array}$ & $\begin{array}{l}\text { - parents cannot terminate } \\
\text { this custody, only the court } \\
\text { can revoke this custody } \\
\text { because it is legal }\end{array}$ & $\begin{array}{l}\text { - grandparent and parent are } \\
\text { in agreement } \\
\text { - grandparent is not trying to } \\
\text { strengthen custody by } \\
\text { proving parent to be unfit }\end{array}$ \\
\hline Guardianship & $\begin{array}{l}\text { - legal form of custody } \\
\text { - two types: person and } \\
\text { property (material } \\
\text { belongings) } \\
\text { - permanent until child } \\
\text { is } 18 \text { or court removes } \\
\text { guardianship } \\
\text { - next to adoption, this } \\
\text { is one of the most } \\
\text { secure and permanent } \\
\text { relationships }\end{array}$ & - grandparent has all authority over child & $\begin{array}{l}\text { - parental rights do not have } \\
\text { to be terminated }\end{array}$ & $\begin{array}{l}\text { - grandparent desires long- } \\
\text { term commitment and } \\
\text { wants authority to make } \\
\text { decisions }\end{array}$ \\
\hline Adoption & $\begin{array}{l}\text { - most permanent legal } \\
\text { custody } \\
\text { - can happen when } \\
\text { parent consents or } \\
\text { court has terminated } \\
\text { parental rights }\end{array}$ & - grandparent has all authority over child & - parents lose their rights & $\begin{array}{l}\text { - grandparent is determined } \\
\text { to have the most secure, } \\
\text { permanent custody for the } \\
\text { child } \\
\text { - parent's rights have been } \\
\text { terminated }\end{array}$ \\
\hline
\end{tabular}




\section{Custody Options With Department of Children and Families (DCF) Involvement}

\begin{tabular}{|c|c|c|c|c|}
\hline & Description & Grandparent's rights & Parent's rights & Best choice if ... \\
\hline $\begin{array}{l}\text { Court Ordered } \\
\text { Placement }\end{array}$ & $\begin{array}{l}\text { - grandparent has } \\
\text { physical custody } \\
\text { - DCF mandates } \\
\text { ongoing supervision } \\
\text { - DCF has supervising } \\
\text { authority }\end{array}$ & $\begin{array}{l}\text { - grandparent can make day-to-day } \\
\text { decisions about grandchild } \\
\text { - grandparent is provided with needed } \\
\text { services by DCF caseworker }\end{array}$ & $\begin{array}{l}\text { - parent can work on } \\
\text { case plan to get child back } \\
\text { - parent is provided with } \\
\text { needed services by DCF } \\
\text { caseworker }\end{array}$ & $\begin{array}{l}\text { - you believe parent is } \\
\text { working hard and is } \\
\text { committed to following the } \\
\text { case plan to get child back }\end{array}$ \\
\hline $\begin{array}{l}\text { Temporary Legal } \\
\text { Custody }\end{array}$ & $\begin{array}{l}\text { - grandparent has court } \\
\text { ordered legal custody } \\
\text { - DCF mandates } \\
\text { ongoing supervision }\end{array}$ & $\begin{array}{l}\text { - grandparent can make important } \\
\text { decisions about grandchild with minimal } \\
\text { DCF supervision }\end{array}$ & $\begin{array}{l}\text { - parent has visitation rights } \\
\text { - parent can work on case } \\
\text { plan to get child back }\end{array}$ & $\begin{array}{l}\text { - you are uncertain if parent } \\
\text { will follow through with } \\
\text { required case plan }\end{array}$ \\
\hline $\begin{array}{l}\text { Long-Term Legal } \\
\text { Custody }\end{array}$ & $\begin{array}{l}\text { - option granted after } 6 \\
\text { months of DCF } \\
\text { supervision with } \\
\text { temporary legal } \\
\text { custody } \\
\text { - more secure and } \\
\text { permanent } \\
\text { arrangement than } \\
\text { placement or } \\
\text { temporary legal } \\
\text { custody }\end{array}$ & $\begin{array}{l}\text { - grandparent has full authority over } \\
\text { grandchild }\end{array}$ & $\begin{array}{l}\text { - parents can regain custody } \\
\text { if they can prove that: } \\
\text { - the situation that } \\
\text { caused them to lose } \\
\text { custody has changed } \\
\text { - living with the parent(s) } \\
\text { is best for the child }\end{array}$ & $\begin{array}{l}\text { - parent consents to } \\
\text { grandparent having long- } \\
\text { term legal custody } \\
\text { - parent's rights have been } \\
\text { terminated } \\
\text { - parent does not follow case } \\
\text { plan as instructed by courts }\end{array}$ \\
\hline Adoption & $\begin{array}{l}\text { - most permanent legal } \\
\text { custody } \\
\text { - occurs upon consent } \\
\text { of parent or court has } \\
\text { terminated parental } \\
\text { rights }\end{array}$ & - grandparent has all authority over child & - parents lose their rights & $\begin{array}{l}\text { - grandparent is determined } \\
\text { to have the most secure, } \\
\text { permanent custody for the } \\
\text { child } \\
\text { parent's rights have been } \\
\text { terminated }\end{array}$ \\
\hline
\end{tabular}




\section{Where to Find Help About Legal Issues}

If you need additional information about legal matters, contact the following services.

- Lawyer Referral Service - This is a public service of the Florida Bar Association. By calling 1-800-342-8060, you will be referred to a lawyer. The lawyer will provide an initial 30 minute consultation for free or a small fee.

- Attorney - Look in the yellow pages for an one who specializes in family law.

- Department of Children and Families If you call 1-800-342-8025, you can find out about the services available in your community.

- Family Mediation - The number for your area is found in the blue pages (government pages) of your phone book. Look under Court Administrator's office.

- Department of Social Services - The number for your area is found in the blue pages of your phone book under Social Services.

\section{Links to More Information}

- $\underline{w w w . g r a n d p a r e n t a g a i n . c o m}$

- $\underline{\text { www.aarp.org }}$

- $\underline{w w w . f l a b a r . o r g}$

\section{Answers to page 2:}

1. adoption

2. temporary legal custody

3. physical custody

4. long-term legal custody

*This publication uses "he", "his", or "him" to represent children of both genders

\section{References:}

AARP Grandparent Information Center. Grandparents Raising Their Grandchildren: Where to Find Help. http://www.aarp.org/confacts/programs/grandrai sing.html

Kinship Support Center, University of South Florida School of Social Work http://www.cas.usf.edu/ krisman/

The 2000 Florida Statues: Chapter 39. http://www.leg.state.fl.us

Zawesa, C.A. \& Ratliff, J. M. (2000) Kinship Care Legal Handbook. Nova Southeastern University. Fort Lauderdale, FL.

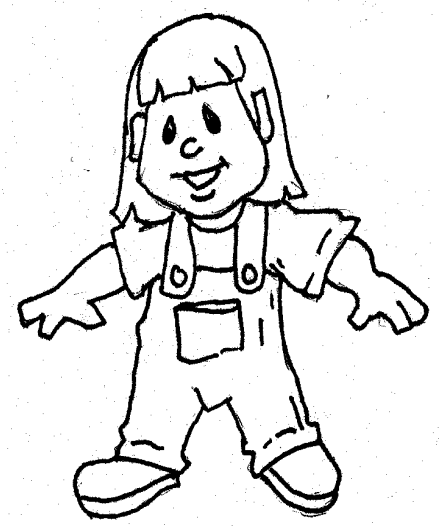

